\title{
Serological, molecular, and microscopic detection of Leishmania in cats (Felis catus) in Belo Horizonte, Minas Gerais State, Brazil
}

\author{
Detecção sorológica, molecular e microscópica de Leishmania em gatos (Felis catus) em Belo Horizonte, \\ Minas Gerais, Brasil
}

Fernanda Morcatti Coura ${ }^{1}$; Stephanie Karoline Pereira Passos²; Marina de Oliveira França Pelegrinoº; Fabiola de Oliveira Paes Leme ${ }^{2}$; Gustavo Fontes Paz ${ }^{3}$; Célia Maria Ferreira Gontijo ${ }^{3}$; Adriane Pimenta da Costa-Val ${ }^{2 *}$

\begin{abstract}
'Departamento de Ciências Agrárias, Instituto Federal de Minas Gerais, Campus Bambuí, Fazenda Varginha, Bambuí, MG, Brasil
${ }^{2}$ Departamento de Clinica e Cirurgia Veterinárias, Universidade Federal de Minas Gerais - UFMG, Belo Horizonte, MG, Brasil

${ }^{3}$ Instituto René Rachou - Fiocruz Minas, Belo Horizonte, MG, Brasil
\end{abstract}

Received February 08, 2018

Accepted June 13, 2018

\begin{abstract}
The role of cats in the epidemiological cycle of leishmaniasis remains unclear. To better understand the occurrence of leishmaniasis in cats, we studied the frequency of Leishmania in serum samples of 100 cats living in an endemic region for canine and human leishmaniasis by serological, parasitological, and molecular methods. Of the 100 cats, 54 were seropositive for Leishmania antibodies by immunofluorescence antibody test. None of the bone marrow aspirates collected from these cats tested positive for the parasite in culture or upon polymerase chain reaction (PCR) analysis. Biopsy samples of the ears also tested negative for Leishmania upon PCR analysis. These findings may indicate that the region is endemic for canine leishmaniasis and cats are infected by Leishmania; or that cross-reaction with antibodies against other parasites increases the frequency of seropositivity; or that cats respond to Leishmania infection by producing antibodies when few or no parasites are present in bone marrow and tissue samples. Overall, our results suggest that cats can be infected by Leishmania; however, we failed to demonstrate feline parasitosis. These findings highlight the need to study leishmaniasis in cats, since sandflies feed on cats, these animals may act as a reservoir for the parasite.
\end{abstract}

Keywords: Diagnosis, feline leishmaniasis, reservoir.

\section{Resumo}

O papel dos gatos no ciclo epidemiológico da leishmaniose ainda não está claro. Para entender melhor a ocorrência de leishmaniose em gatos, estudou-se a frequência de Leishmania em amostras de soro de 100 gatos, os quais vivem em uma região endêmica para leishmaniose canina e humana, por métodos sorológicos, parasitológicos e moleculares. Dos 100 gatos, 54 foram soropositivos para anticorpos de Leishmania por teste de anticorpos de imunofluorescência. Nenhum dos aspirados de medula óssea coletados desses gatos mostrou-se positivo para o parasita em cultura, ou após a realização da reação em cadeia da polimerase (PCR). Amostras de biópsia das orelhas também foram negativas para Leishmania submetidas a PCR. Esses achados indicam que na regiáo estudada endêmica para leishmaniose canina, os gatos podem se infectar por Leishmania; ou que a reação cruzada com anticorpos contra outros parasitas aumenta a frequência de soropositividade; ou que os gatos respondem à infecçáo por Leishmania produzindo anticorpos quando poucos ou nenhum parasita estáo presentes na medula óssea e em amostras de tecido. Em geral, os resultados sugerem que os gatos podem ser estar infectados por Leishmania spp. No entanto, não foi possível demonstrar parasitismo felino. Essas descobertas evidenciam a necessidade de estudar a leishmaniose em gatos, uma vez que, como os flebotomíneos se alimentam em gatos, e esses animais podem atuar como um reservatório para o parasita.

Palavras-chave: Diagnóstico, leishmaniose felina, reservatório.

*Corresponding author: Adriane Pimenta da Costa-Val. Departamento de Clínica e Cirurgia Veterinárias, Universidade Federal de Minas Gerais, Av. 


\section{Introduction}

Visceral leishmaniasis (VL) is a zoonosis caused by Leishmania infantum, an endemic parasite in over 70 countries worldwide (BANETH et al., 2008). Dogs are considered the main reservoir of the parasite in domestic and peridomestic areas; however, since recent studies have reported that cats may become infected with the protozoan, questions have been raised regarding the epidemiological role of cats in the zoonotic cycle and their potential as parasite reservoirs (MAIA \& CAMPINO, 2011).

Leishmaniasis is transmitted by the bite of female phlebotomine sandflies, mainly Lutzomyia longipalpis and Lutzomyia cruzi in Brazil. Although rarely seen, the most frequent clinical signs of leishmaniasis in cats include skin changes such as papules, nodules, ulcers, and alopecia (SILVEIRA et al., 2015). Leishmania species identified in cats include Leishmania mexicana, Leishmania venezuelensis, Leishmania braziliensis, Leishmania amazonensis, and L. infantum (PENNISI et al., 2015).

Multiple studies have examined the seroprevalence of Leishmania (CARDIA et al., 2013; SILVA et al., 2014; BRAGA et al., 2014; NOÉ et al., 2015; OLIVEIRA et al., 2015; BALDINI-PERUCA et al., 2017) and the occurrence of natural cases of leishmaniasis (PASSOS et al., 1996; SCHUBACH et al., 2004; SOUZA et al., 2005) in cats in Brazil. However, experimental studies on leishmaniasis in cats are scarce (KIRKPATRICK et al., 1984; SIMÓES-MATTOS et al., 2005), and reports regarding the evaluation of the cellular immune response against the parasite are lacking (PENNISI et al., 2015). Such studies could help understand the rarity of clinical signs observed in cats infected with Leishmania spp. as well as the corresponding immune response, thereby helping to standardize diagnostic procedures.

Because of the suggestion that cats could serve as potential reservoirs of Leishmania spp., the objective of the present study was to investigate the occurrence of $L$. infantum infection in cats living in an endemic region for canine leishmaniasis (CL) and human $\mathrm{VL}$, using serological, parasitological, and molecular methods.

\section{Materials and Methods}

The experimental group consisted of 100 cats (Felis catus) that were randomly selected from among 250 cats rescued from streets and housed in a shelter for animals in Belo Horizonte, Minas Gerais, Brazil. The city is endemic for $\mathrm{CL}$ and has registered cases of human VL. As the cats previously lived on the streets, the shelter could not provide any details regarding breed, sex, or age of the animals.

The cats were clinically evaluated before blood sample collection. Physical examination consisted of general appearance, body condition, weight, temperature, hydration status, mucous membrane color, capillary refill time, palpation of lymph nodes, heart and respiratory rates, abdominal palpation, and examination of the skin and haircoat. All cats were clinically regarded as asymptomatic. The experimental procedures were approved by the Ethics Committee on Animal Experimentation, Universidade Federal de Minas Gerais (CETEA 242/2014), prior to the start of this study.
Using disposable syringes and needles, blood samples were collected from the jugular or cephalic vein and transferred into tubes without ethylenediaminetetraacetic acid. These samples were centrifuged at $1500 \mathrm{x}$ for $15 \mathrm{~min}$, and the separated serum was transferred into plastic microtubes and stored at $-20^{\circ} \mathrm{C}$ until serological analysis. The serum samples were tested for Leishmania antibodies via the indirect immunofluorescence antibody test (IFAT) (VIDES et al., 2011). Cats were categorized as seropositive on the basis of the cutoff point (40 UI) that was previously suggested for dogs (MINISTÉRIO DA SAÚDE, 2000).

Cats found to be seropositive according to the IFAT were further evaluated through parasitological analysis of bone marrow aspirates collected from the tibial tuberosity. Bone marrow samples were collected for cytological smear, culture, and polymerase chain reaction (PCR) analyses.

In order to investigate the presence of amastigotes, smears of bone marrow aspirates were fixed and stained with a panoptic stain (May-Grünwald Giemsa) and examined under an optical microscope $(100 x)$. To investigate the presence of promastigote forms, bone marrow samples were cultured in Novy-MacNeal-Nicolle (NNN) medium, supplemented with liver infusion tryptose medium (SCHUSTER \& SULLIVAN, 2002). These samples were incubated at $25^{\circ} \mathrm{C}$ and examined weekly for 8 weeks under an optical microscope. Bone marrow aspirates from seropositive animals were subjected to PCR analysis to detect Leishmania minicircle kinetoplast DNA (kDNA), as described by DEGRAVE et al. (1994) and PASSOS et al. (1996). Briefly, PCR was performed in a total volume of $25 \mu \mathrm{L}$ of a mixture containing $5 \mu \mathrm{L}$ of DNA template, $0.2 \mathrm{mM}$ of DNTPs, $1.5 \mathrm{mM} \mathrm{MgCl} 2,1.5 \mu \mathrm{L}$ of DMSO $5 \%, 0.4 \mu \mathrm{M}$ of each primer, buffer (10 mM Tris- $\mathrm{HCl}, 50 \mathrm{mM} \mathrm{KCl}, \mathrm{pH} 8.0)$ and $1.25 \mathrm{U}$ of Taq DNA polymerase (Invitrogen ${ }^{\mathrm{Tm}}$; Carlsbad, CA, USA). PCR conditions were as follows: initial denaturation at $94^{\circ} \mathrm{C}$ for $5 \mathrm{~min}$, followed by 35 cycles at $94^{\circ} \mathrm{C}$ for $30 \mathrm{sec}, 61^{\circ} \mathrm{C}$ for $1 \mathrm{~min}, 72^{\circ} \mathrm{C}$ for $3 \mathrm{~min}$, and a final extension at $72^{\circ} \mathrm{C}$ for $10 \mathrm{~min}$. Negative and positive PCR controls were included in each reaction set. The negative control contained no DNA, whereas the positive controls contained 0.01 and $1.0 \mathrm{pg}$ of standard Leishmania DNA (L. infantum strain MHOM/BR/74/PP75).

In addition, $1 \mathrm{~cm}^{2}$ biopsy samples of ears were collected and stored in RNAlater storage solution (Invitrogen ${ }^{\mathrm{TN}}$; Carlsbad, CA, USA) in microtubes. This site was chosen because experimental models for Leishmania spp. transmission allow sandflies to feed in their ears (SECUNDINO et al., 2012). These samples were processed for DNA extraction in accordance with the manufacturer's instructions (Gentra Puregene Tissue Kit; Qiagen; Valencia, CA, USA). The DNA samples were then subjected to PCR to detect Leishmania minicircle $\mathrm{kDNA}$.

\section{Results}

Of the 100 feline serum samples collected, 54 were found to be positive for Leishmania antibodies on the basis of IFAT findings.

Cytological smears of all bone marrow aspirates were negative for Leishmania amastigotes. Similarly, none of the culture samples were positive for promastigote forms during the 8 -week period. 
There were no instances of contamination of culture. The results of PCR analysis revealed the bone marrow and biopsy samples did not find for Leishmania.

\section{Discussion}

The maintenance and spread of vector-borne diseases depends on the availability of infected hosts to serve as parasite reservoirs. In the case of leishmaniasis, it is important to understand the epidemiological impact of asymptomatic hosts in the transmission of the parasite to new vectors (SADLOVA et al., 2015). Previous studies in Brazil and other countries have emphasized the importance of feline leishmaniasis. However, there remain many questions to be answered. The present study was conducted in Belo Horizonte, Minas Gerais. The prevalence of leishmaniasis in the canine and human populations in this state is worrying. In 2016, Minas Gerais registered 492 cases of human VL, with 2.3 cases per 100,000 inhabitants and 54 deaths. Belo Horizonte registered a high number of cases of VL in humans and CL in dogs (BRASIL, 2017). A study conducted in Belo Horizonte showed a highly significant correlation between the incidence of human VL and the prevalence rates of CL (OLIVEIRA et al., 2001). Although dogs are the main hosts and reservoir for L. infantum (MAIA \& CAMPINO, 2011), our study found $54 \%$ of the evaluated cats to be seropositive, thus reinforcing previous findings that cats can be infected with Leishmania spp.

The frequency of leishmaniasis in cats determined using serological tests varies among regions. A study in Angola found none of the evaluated cats to be seropositive (MARTÍN-SÁNCHEZ et al., 2007) and 3.87\% in Greece (DIAKOU et al., 2009). In Brazil, the frequency of leishmaniasis in cats has been reported as follows: $4.06 \%$ in Belém (OLIVEIRA et al., 2015); 3.9\% in Pernambuco (SILVA et al., 2014); 7.27\% (NOÉ et al., 2015) to $30 \%$ (BRAGA et al., 2014) in Mato Grosso do Sul and $0.52 \%$ (CARDIA et al., 2013) to 2.8\% (BALDINI-PERUCA et al., 2017) in São Paulo.

The high frequency of feline leishmaniasis observed in the present study can be explained by the high prevalence of CL in the area of this study. In endemic areas for CL, cats can become infected with Leishmania spp. and act as secondary reservoirs in the presence of the primary reservoir, dogs (PENNISI et al., 2015). It is important to highlight that the cat flea Ctenocephalides felis felis, which can mechanically transmit $L$. infantum, can also infect dogs (PAZ et al., 2013).

Additionally, a previous study suggested that, at low serum dilutions, such as were used in the present study, remnants of the dye used in the IFAT might be misidentified as being fluorescent (CHATZIS et al., 2014b). Another hypothesis for the high frequency of feline leishmaniasis observed in the present study is the possibility of cross-reaction with antibodies against other parasites (ANDRADE et al., 2009; LUCIANO et al., 2009; SOARES et al., 2016).

All cats in the present study were asymptomatic and tested negative for Leishmania spp. upon parasitological and molecular analysis of bone marrow aspirates. Moreover, upon PCR screening, all tissue biopsy samples were found to be negative for Leishmania spp. These findings are of great importance. First, they demonstrate that cats are infected with and produce antibodies against Leishmania spp., although they do not host parasites at the body sites evaluated in this study. Second, the diagnosis of feline leishmaniasis solely on the basis of serological findings might lead to misdiagnosis of cats as positive carriers of the disease, especially in endemic areas.

Absence of Leishmania DNA or parasites in seropositive cats has been reported previously (BRAGA et al., 2014; CHATZIS et al., 2014a; NOÉ et al., 2015). In an experimental infection of cats with L. braziliensis, although all cats exhibited antibodies against the parasite, none exhibited amastigotes in the bone marrow (SIMÓES-MATTOS et al., 2005). Cats infected intradermally or intravenously with $L$. chagasi (KIRKPATRICK et al., 1984) have been reported as capable of responding to the infection by producing antibodies. Humoral immune response and antibody production may be important for protection against feline leishmaniasis. However, these responses are not observed in dogs (MARTÍN-SÁNCHEZ et al., 2007; MAIA \& CAMPINO, 2011). Moreover, studies on the cellular immune response to Leishmania infection in cats, to demonstrate the balance between cellular and humoral response to the infection have not yet been performed as they have been in dogs (MAIA \& CAMPINO, 2011; PENNISI et al., 2015).

There is no consensus regarding the ideal organ for cytological or molecular diagnosis of leishmaniasis, which could explain the absence of parasites in the bone marrow. Some authors have suggested lymph node aspiration (COSTA et al., 2010) or skin biopsy (CHATZIS et al., 2014a). It is necessary to identify the best lymphoid organ to target with aspiration for cytological diagnosis of leishmaniasis (SILVEIRA et al., 2015). Moreover, low parasitemia (below the PCR detection limit) or infection control by the immune response could contribute to the cytological results (CHATZIS et al., 2014a; NOÉ et al., 2015).

\section{Conclusions}

Our findings revealed a high seroprevalence of leishmaniasis in cats living in a city endemic for CL and with reported cases of human VL. However, the parasite was not detected in bone marrow aspirates or ear biopsy samples collected from seropositive cats. This indicates that cats can become infected with, and produce antibodies against, Leishmania spp. Moreover, the feline immune system might clear the infection or contain the parasites within an organ, thus maintaining low levels of parasitemia. Nevertheless, it is not clear whether these antibodies are protective or whether the cellular immune response is effective for infection control in cats. The present results highlight the need to continue standardization of diagnostic procedures for feline leishmaniasis, as well as to investigate the role of cats as reservoirs of Leishmania spp.

\section{Conflict of Interest}

The authors declare that they have no conflict of interest. This research did not receive any specific grant from funding agencies in the public, commercial, or not-for-profit sectors. 


\section{Ethics Approval and Consent to Participate}

All animal care and procedures as well as license for blood sampling were approved by the current national law on animal experimentation and ethics (CONCEA), according to the certificate number CETEA 242/2014 generated by the Ethics Committee on Animal Experimentation of the Universidade Federal de Minas Gerais (UFMG).

\section{References}

Andrade AR, Nunes VL, Galati EA, de Arruda CC, Santos MF, Rocca $\mathrm{ME}$, et al. Epidemiological study on leishmaniasis in an area of environmental tourism and ecotourism, State of Mato Grosso do Sul, 2006-2007. Rev Soc Bras Med Trop 2009; 42(5): 488-493. http://dx.doi.org/10.1590/ S0037-86822009000500003. PMid:19967228.

Baldini-Peruca L, Lucheis S, Tome RO, Richini-Pereira VB, Correa APFL, Troncarelli MZ, et al. Leishmania infantum (syn. chagasi) infection in cats from a Brazilian southeastern endemic area for canine and human leishmaniasis. Vet Zootec 2017; 24(1): 216-225.

Baneth G, Koutinas AF, Solano-Gallego L, Bourdeau P, Ferrer L. Canine leishmaniosis - new concepts and insights on an expanding zoonosis: part one. Trends Parasitol 2008; 24(7): 324-330. http://dx.doi.org/10.1016/j. pt.2008.04.001. PMid:18514028.

Braga ARC, Langoni H, Lucheis SB. Evaluation of canine and feline leishmaniasis by the association of blood culture, immunofluorescent antibody test and polymerase chain reaction. J Venom Anim Toxins Incl Trop Dis 2014; 20(1): 5. http://dx.doi.org/10.1186/1678-9199-20-5. PMid:24565284.

Brasil. Ministério da Saúde. Fundação Nacional de Saúde. Centro Nacional de Epidemiologia. Doenças infecciosas e parasitárias: aspectos clínicos, vigilância epidemiológica e medidas de controle [online]. Brasília: Ministério da Saúde; 2000 [cited 2017 Oct 27]. Available from: http:// bvsms.saude.gov.br/bvs/publicacoes/funasa/GBDIP001_total.pdf.

Brasil. Ministério da Saúde. Situação epidemiológica Leishmaniose visceral [online]. Brasília: Ministério da Saúde; 2017 [cited 2017 Oct 27]. Available from: http://portalms.saude.gov.br/saude-de-a-z/leishmaniosevisceral/11334-situacao-epidemiologica-dados.

Cardia DFF, Camossi LG, Neto LS, Langoni H, Bresciani KDS. Prevalence of Toxoplasma gondii and Leishmania spp. infection in cats from Brazil. Vet Parasitol 2013; 197(3-4): 634-637. http://dx.doi.org/10.1016/j. vetpar.2013.07.017. PMid:23932640.

Chatzis MK, Andreadou M, Leontides L, Kasabalis D, Mylonakis M, Koutinas AF, et al. Cytological and molecular detection of Leishmania infantum in different tissues of clinically normal and sick cats. Vet Parasitol 2014a; 202(3-4): 217-225. http://dx.doi.org/10.1016/j.vetpar.2014.02.044. PMid:24629427.

Chatzis MK, Leontides L, Athanasiou LV, Papadopoulos E, Kasabalis D, Mylonakis M, et al. Evaluation of indirect immunofluorescence antibody test and enzyme-linked immunosorbent assay for the diagnosis of infection by Leishmania infantum in clinically normal and sick cats. Exp Parasitol 2014b; 147: 54-59. http://dx.doi.org/10.1016/j.exppara.2014.10.004. PMid:25307685.

Costa TAC, Rossi CN, Laurenti MD, Gomes AAD, Vides JP, Vicente Sobrinho LS, et al. Ocorrência de leishmaniose em gatos de área endêmica para leishmaniose visceral. BrazJVet Res Anim Sci 2010; 47(3): 213-217. http://dx.doi.org/10.11606/issn.1678-4456.bjvras.2010.26858.

Degrave W, Fernandes O, Campbell D, Bozza M, Lopes U. Use of molecular probes and PCR for detection and typing of Leishmania - a mini-review. Mem Inst Oswaldo Cruz 1994; 89(3): 463-469. http://dx.doi. org/10.1590/S0074-02761994000300032. PMid:7476234.

Diakou A, Papadopoulos E, Lazarides K. Specific anti-Leishmania spp. antibodies in stray cats in Greece. J Feline Med Surg 2009; 11(8): $728-$ 730. http://dx.doi.org/10.1016/j.jfms.2008.01.009. PMid:19254858.

Kirkpatrick CE, Farrell JP, Goldschmidt MH. Leishmania chagasi and L. donovani: experimental infections in domestic cats. Exp Parasitol 1984; 58(2): 125-131. http://dx.doi.org/10.1016/0014-4894(84)90027-4. PMid:6479284.

Luciano RM, Lucheis SB, Troncarelli MZ, Luciano DM, Langoni H. Avaliação da reatividade cruzada entre antígenos de Leishmania spp e Trypanosoma cruzi na resposta sorológica de cães pela técnica de imunofluorescência indireta (RIFI). BrazJVet Res Anim Sci 2009; 46(3): 181-187. http://dx.doi.org/10.11606/issn.1678-4456.bjvras.2009.26765.

Maia C, Campino L. Can domestic cats be considered reservoir hosts of zoonotic leishmaniasis? Trends Parasitol 2011; 27(8): 341-344. http:// dx.doi.org/10.1016/j.pt.2011.03.008. PMid:21570915.

Martín-Sánchez J, Acedo C, Muñoz-Pérez M, Pesson B, Marchal O, MorillasMárquez F. Infection by Leishmania infantum in cats: Epidemiological study in Spain. Vet Parasitol 2007; 145(3-4): 267-273. http://dx.doi. org/10.1016/j.vetpar.2006.11.005. PMid:17157440.

Noé P, Domingos SL, Oshiro ET, Lima RB, Pirmez C, Pedroso TC, et al. Detection of Leishmania chagasi in cats (Felis catus) from viscera leishmaniasis endemic area in Brazil. Ciênc Anim 2015; 25(4): 3-14.

Oliveira CD, Assunção RM, Reis IA, Proietti FA. Spatial distribution of human and canine visceral leishmaniasis in Belo Horizonte, Minas Gerais State, Brasil, 1994-1997. Cad Saude Publica 2001; 17(5): 1231-1239. http://dx.doi.org/10.1590/S0102-311X2001000500023. PMid:11679897.

Oliveira GC, Paiz LM, Menozzi BD, Lima MS, Moraes CC, Langoni H. Antibodies to Leishmania spp. in domestic felines. Rev Bras Parasitol Vet 2015; 24(4): 464-470. http://dx.doi.org/10.1590/S1984-29612015071. PMid:26689182.

Passos VM, Lasmar EB, Gontijo CM, Fernandes O, Degrave W. Natural infection of a domestic cat (Felis domesticus) with Leishmania (Viannia) in the metropolitan region of Belo Horizonte, state of Minas Gerais, Brazil. Mem Inst Oswaldo Cruz 1996; 91(1): 19-20. http://dx.doi.org/10.1590/ S0074-02761996000100003. PMid:8734945.

Paz GF, Reis IA, Avelar DM, Mata Ferreira EC, Werneck GL. Ectoparasites and anti-Leishmania antibodies: Association in an observational casecontrol study of dogs from a Brazilian endemic area. Prev Vet Med 2013; 112(1-2): 156-159. http://dx.doi.org/10.1016/j.prevetmed.2013.07.012. PMid:23932895.

Pennisi MG, Cardoso L, Baneth G, Bourdeau P, Koutinas A, Miró $\mathrm{G}$, et al. LeishVet update and recommendations on feline leishmaniosis. Parasit Vectors 2015; 8(1): 302. http://dx.doi.org/10.1186/s13071-0150909-z. PMid:26041555.

Sadlova J, Seblova V, Votypka J, Warburg A, Volf P. Xenodiagnosis of Leishmania donovani in BALB/c mice using Phlebotomus orientalis: a new laboratory model. Parasit Vectors 2015; 8(1): 158. http://dx.doi. org/10.1186/s13071-015-0765-x. PMid:25881258.

Schubach TMP, Figueiredo FB, Pereira SA, Madeira MF, Santos IB, Andrade MV, et al. American cutaneous leishmaniasis in two cats from 
Rio de Janeiro, Brazil: First report of natural infection with Leishmania (Viannia) braziliensis. Trans R Soc Trop Med Hyg 2004; 98(3): 165-167. http://dx.doi.org/10.1016/S0035-9203(03)00040-3. PMid:15024926.

Schuster FL, Sullivan JJ. Cultivation of Clinically Signicant Hemofagellates. Clin Microbiol Rev 2002; 15(3): 374-389. http://dx.doi.org/10.1128/ CMR.15.3.374-389.2002. PMid:12097246.

Secundino NF, Freitas VC, Monteiro CC, Pires AC, David BA, Pimenta PF. The transmission of Leishmania infantum chagasi by the bite of the Lutzomyia longipalpis to two different vertebrates. Parasit Vectors 2012; 5(1): 20. http://dx.doi.org/10.1186/1756-3305-5-20. PMid:22260275.

Silva RCN, Ramos RAN, Pimentel DS, Oliveira GM, Carvalho GA, Santana MA, et al. Detection of antibodies against Leishmania infantum in cats (Felis catus) from the state of Pernambuco, Brazil. Rev Soc Bras Med Trop 2014; 47(1): 108-109. http://dx.doi.org/10.1590/0037-86820005-2012. PMid:24603746.

Silveira LD No, Marcondes M, Bilsland E, Matos LVS, Viol MA, Bresciani KDS. Clinical and epidemiological aspects of feline leishmaniasis in Brazil. Semina: Ciênc Agrár 2015; 36(3): 1467-1480. http://dx.doi. org/10.5433/1679-0359.2015v36n3p1467.
Simóes-Mattos L, Mattos MRF, Teixeira MJ, Oliveira-Lima JW, Bevilaqua CML, Prata-Júnior RC, et al. The susceptibility of domestic cats (Felis catus) to experimental infection with Leishmania braziliensis. Vet Parasitol 2005; 127(3-4): 199-208. http://dx.doi.org/10.1016/j.vetpar.2004.10.008. PMid:15710520.

Soares CSA, Duarte SC, Sousa SR. What do we know about feline leishmaniosis? J Feline Med Surg 2016; 18(6): 435-442. http://dx.doi. org/10.1177/1098612X15589358. PMid:26116620.

Souza AI, Barros EM, Ishikawa E, Ilha IM, Marin GR, Nunes VL. Feline leishmaniasis due to Leishmania (Leishmania) amazonensis in Mato Grosso do Sul State, Brazil. Vet Parasitol 2005; 128(1-2): 41-45. http://dx.doi. org/10.1016/j.vetpar.2004.11.020. PMid:15725531.

Vides JP, Schwardt TF, Sobrinho LSV, Marinho M, Laurenti MD, Biondo AW, et al. Leishmania chagasi infection in cats with dermatologic lesions from an endemic area of visceral leishmaniosis in Brazil. Vet Parasitol 2011; 178(1-2): 22-28. http://dx.doi.org/10.1016/j.vetpar.2010.12.042. PMid:21282011. 